\title{
Detection of Mycobacterium kansasii Using DNA-DNA Hybridization with rpoB Probe
}

\author{
Tae-Dong Kweon ${ }^{1}$, Sun-Joon Bai ${ }^{1}$, Chang-Shik $\mathrm{Choi}^{2}$, and Seong-Karp Hong ${ }^{3 *}$, Member, KIICE \\ ${ }^{1}$ Department of Anesthesiology and Pain Medicine, Yonsei University College of Medicine, Seoul 120-749, Korea \\ ${ }^{2}$ Department of Oriental Medicine Resources, Far East University, Eumseong 369-700, Korea \\ ${ }^{3}$ Division of Bio and Health Sciences, Mokwon University, Daejeon 302-729, Korea
}

\begin{abstract}
A microtiter well plate DNA hybridization method using Mycobacterium kansasii-specific rpoB DNA probe (kanp) were evaluated for the detection of $M$. kansasii from culture isolates. Among the 201 isolates tested by this method, 27 strains show positive results for $M$. kansasii, but the other 174 isolates were negative results for $M$. kansasii. This result was consistent with partial $r р о B$ sequence analysis of $M$. kansasii and the result of biochemical tests. The negative strains by this DNA-DNA hybridization method were identified as Mycobacterium tuberculosis (159 strains), Mycobacterium avim (5 strains), Mycobacterium intracellulare (8 strains), and Mycobacterium flavescens (2 strain) by rpoB DNA sequence analysis. Due to high sensitivity and specificity of this test result, we suggest that DNA-DNA hybridization method using rpoB DNA probes of M. kansasii could be used for the rapid and convenient detection of M. kansasii.
\end{abstract}

Index Terms: DNA, Hybridization, Mycobacterium kansasii,

\section{INTRODUCTION}

Mycobacterium kansasii has been considerably pathogenic mycobacteria causing various human diseases with nontuberculous mycobacteria containing $M$. avium and M. intracellulare. It is the most common cause of nontuberculous mycobacterial lung disease in Europe [1, 2]. Detection and identification of mycobacteria is very important for epidemiological survey of disease and adequate drug use. Conventionally identification methods of mycobacteria are mainly biochemical tests of acid-fast isolates. These methods are not economical in view of time and expense. Lately, many molecular approaches for the identification of mycobacteria have been developed. Among them, The INNO-LiPA MYCOBACTERIA assay (LiPA; Innogenetics, Ghent, Belgium) using 16S-23S internal transcribed spacer (ITS) region is very specific and sensitive [3]. However, it is hard to identify some mycobacteria and has not yet been fully evaluated. Besides identification of mycobacteria using 16S rRNA gene, ITS, hsp65, sodA, and are sensitive and specific, but are too expensive [4].

In this study, novel M. kansasii-specific probe derived from $r p o B$ was used to separately detect $M$. kansasii from 201 mycobacteria isolates.

\section{MATERIALS AND METHODS}

\section{A. Bacteria Strains and DNA Preparations}

Clinical isolates used in this study were provided by the Korean Institute of Tuberculosis and Department of Clinical

Received 09 April 2012, Revised 04 May 2012, Accepted 09 May 2012

*Corresponding Author E-mail: karp@mokwon.ac.kr 
Pathology, Seoul National University Hospital. Mycobacterial DNA samples were prepared by the bead beater-phenol extraction method [5].

\section{B. Amplication of DNA}

A set of primers, which was previously used to amplify rрoB DNA (351 bp) encompassing the rif $r$ (region associated with rifampin resistance in Mycobacteria) [5], was labeled with biotin and designated BioMF (5'biotinCGACCACTTCGGCAACCG3') and BioMR (5'biotinTCGATCGGGCACATCCGG3'). Template DNA (approximately $50 \mathrm{ng}$ ) and $20 \mathrm{pmol}$ of each primer (BioMF and BioMR) were added to a PCR mixture tube (AccuPower PCR PreMix; Bioneer, Daejeon, Korea) containing 1 $\mathrm{U}$ of Taq DNA polymerase, $250 \mu \mathrm{M}$ dNTP, $50 \mathrm{mM}$ Tris$\mathrm{HCl}$ (pH 8.3), $40 \mathrm{mM} \mathrm{KCl}, 1.5 \mathrm{mM} \mathrm{MgCl}$, and gel loading dye; the volume was then adjusted with distilled water to 20 $\mu \mathrm{L}$. The reaction mixture was subjected to 30 cycles of amplification $\left(5\right.$ minutes at $94^{\circ} \mathrm{C}, 1$ minute at $95^{\circ} \mathrm{C}, 30$ seconds at $68^{\circ} \mathrm{C}, 1$ minute and 20 seconds at $72^{\circ} \mathrm{C}$ ), and this was followed by a 10 minutes extension at $72^{\circ} \mathrm{C}$.

\section{DNA Hybridization in a Microtiter Well Plate}

DNA hybridization was performed as previously described [6], with minor modification (Fig. 1). Briefly, a oligonucleotide-specific probe, kanp (5'-GCC-AGC-TCTCCC-AGT-TCA-3') was designed from the known rpoB sequences of $M$. kansasii [5].

Five picomoles of the probe DNAs was dissolved in 50 $\mu \mathrm{L}$ of immobilization buffer $(1.5 \mathrm{M} \mathrm{NaCl}, 0.3 \mathrm{M}$ Tris- $\mathrm{HCl}$ [pH 8.0], $0.3 \mathrm{M} \mathrm{MgCl}_{2}$ ) and then dispensed into a microtiter well (NucleoLink Strips; Nunc, Rochester, NY, USA) and incubated over night at $37^{\circ} \mathrm{C}$. The probe DNA mixture was then removed from the well and dried at $37^{\circ} \mathrm{C}$ for 30 min. Wells were UV irradiated at $254 \mathrm{~nm}$, for 5 minutes using an electronic UV crosslinker CEX-800 (Ultra-Lum, Claremont, CA, USA) and washed three times with $200 \mu \mathrm{L}$ of washing buffer ( $1 \mathrm{M} \mathrm{NaCl}, 0.1 \mathrm{M}$ Tris- $\mathrm{HCl}$ [pH 9.3], 2 $\mathrm{mM} \mathrm{MgCl}_{2}, 0.1 \%$ Tween 20). Probe-coated wells was immediately stored at $4{ }^{\circ} \mathrm{C}$ and used for hybridization. One hundred microliters of hybridization solution $(5 \times \mathrm{SSC}, 5 \times$ Denhardt's, $0.2 \%$ SDS, and $200 \mu \mathrm{g} / \mathrm{mL}$ of salmon sperm DNA) was dispensed into a probe-coated micro-titer well. Five microliters of the heat-denatured PCR product was mixed with the hybridization solution and incubated in the well for 30 minutes at $50^{\circ} \mathrm{C}$. The mixture was then removed from the well, which was rinsed three times with $200 \mu \mathrm{L}$ of $2 \times$ SSC. One hundred microliters of alkaline phosphataseconjugated streptavidin solution (Amersham Life Science, Arlington Heights, IL, USA), diluted 1:2000 with incubation solution $(0.3 \mathrm{M} \mathrm{NaCl}, 0.1 \mathrm{M}$ Tris- $\mathrm{HCl}$ [pH 7.5] 2
$\mathrm{mM} \mathrm{MgCl}_{2}, 0.05 \%$ Triton $\mathrm{X}-100$ ), was then added to the well, and incubated for 15 minutes at room temperature. After incubation, the well was rinsed three times with 200 $\mu \mathrm{L}$ of incubation solution, then $100 \mu \mathrm{L}$ of $1 \mathrm{M}$ diethanolamine buffer ( $\mathrm{pH}$ 9.8) containing $0.5 \mathrm{mM} \mathrm{MgCl}_{2}$ and $10 \mathrm{mM}$ p-nitrophenyl phosphate was added, and the whole solution was kept at room temperature for $60 \mathrm{~min}$. The enzyme reaction was stopped using $5 \mu \mathrm{L}$ of $10 \mathrm{M}$ $\mathrm{NaOH}$ and the optical density at $405 \mathrm{~nm}\left(\mathrm{OD}_{405}\right)$ of each well was read using a micro-titer plate reader (Multiskan Ascent; Labsystems, Grand Rapids, OH, USA). The $\mathrm{OD}_{405}$ values of triplicated wells were use to draw a bar graph using SigmaPlot 2000 (Ver. 6.00) (SPSS Inc, Chicago, IL, USA).

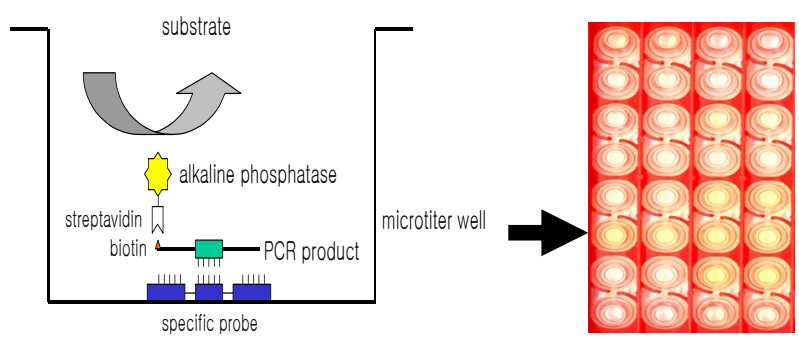

Fig. 1. DNA-DNA hybridization method using kanp probe in microtiter well plate.

\section{Nucleotide Sequencing}

The nucleotide sequences of the purified PCR products were directly determined as previously described [1].

For the sequencing reaction, $60 \mathrm{ng}$ of PCR amplified DNAs, which were purified using a QIAEX II gel extraction kit (QIAGEN, Hilden, Germany), 5 pmol of either the forward or the reverse primer, and $4 \mu \mathrm{L}$ of BigDye Terminator v2.0 100 RR mix (Perkin-Elmer Applied Biosystems, Foster City, CA, USA) were mixed, and the contents were adjusted to a final volume of $10 \mu \mathrm{L}$ with distilled water. The reaction was run for 30 cycles of 10 seconds at $96^{\circ} \mathrm{C}, 5$ seconds at $60^{\circ} \mathrm{C}$, and 4 minutes at $60^{\circ} \mathrm{C}$. Both strands were sequenced as a crosscheck. Determined sequences were compared with those of reference strains in GenBank to compare sequence similarities.

\section{RESULTS}

This specific oligonucleotide probe, kanp probe, for $M$. kansasii were designed by basis on $M$. kansasii specific rроB nucleotide sequence not found in other species of Mycobacterium. The $\mathrm{OD}_{405}$ increased, depending on the concentration of coated this probe and its optimal concentration was evaluated at 5 pmol/well (Fig. 2). The 
average cut-off value of the colorimetric reaction was determined using the amplified rpoB DNAs of M. kansasii, which had been previously identified using culture-based methods.

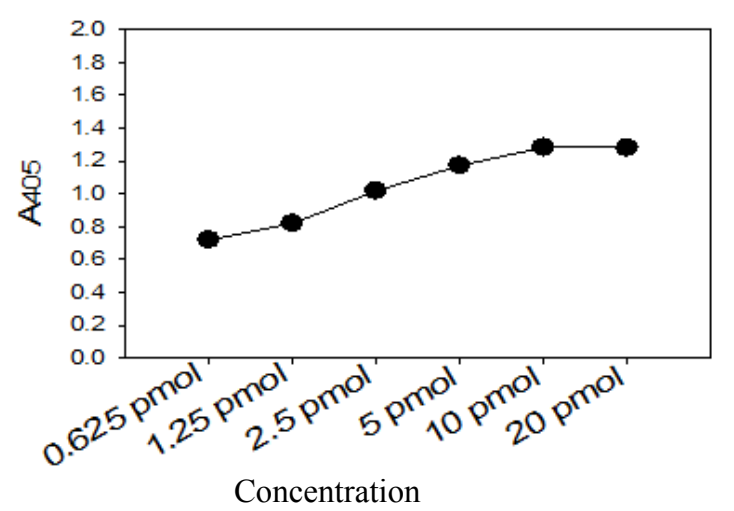

Fig. 2. Determination of concentration of kanp probe in a well by DNADNA hybridization.

This probe also was proved to be specific in terms of the amplification of the rpoB DNA of $M$. kansasii by PCRlinked DNA-DNA hybridization test (Fig. 3).

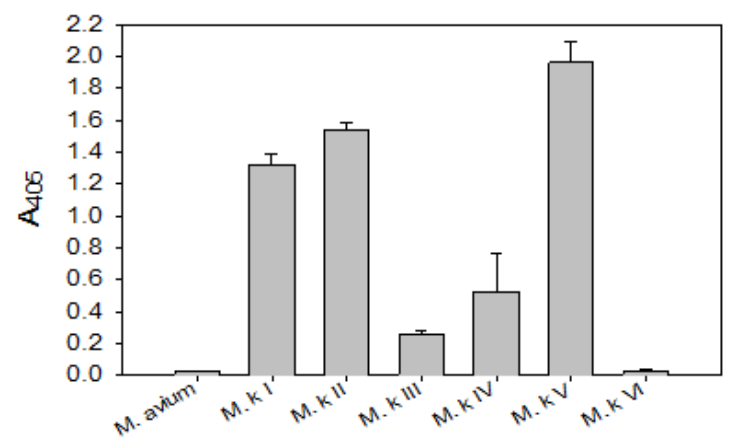

Subtype of M. kansasii

Fig. 3. Identification of $M$. kansasii from subtypes (I, II, III, IV, V, and VI) of $M$. kansasii by DNA-DNA hybridization with kanp probe.

This probe was specific for subtype I, II, IV, and V of $M$. kansasii. There is no problem for detection and identification of M. kansasii from clinical samples because clinical pathogens are subtype I, and II of M. kansasii.

DNA-DNA hybridization test for detection and identification of $M$. kansasii, the average $\mathrm{OD}_{405}$ for positive samples $(n=30)$ was $1.25 \pm 0.32$ and that of negative samples $(n=152)$ was $0.03 \pm 0.02$. Thus, the cut off value for hybridization test using kanp probe were set at 0.2 . Reference strains other than members of the M. kansasii did not react with probes coated onto a micro-titer well plate.
The DNA-DNA hybridization test was also performed with 201 clinical culture samples. Positive reactions, which mean M. kansasii were clearly identified. When kanp probe was used in DNA-DNA hybridization test, of the 201 strains, 27 strains (13.4\%) produced positive results and 174 strains $(86.6 \%)$ were negative (Table 1$)$.

Table 1. Comparision of the results obtained by DNA-DNA hybridization method and other methods for identification of $M$. kansasii

\begin{tabular}{lccc}
\hline \multirow{2}{*}{$\begin{array}{c}\text { Identified } \\
\text { species }\end{array}$} & \multicolumn{3}{c}{ Methods } \\
\cline { 2 - 4 } & $\begin{array}{c}\text { DNA-DNA } \\
\text { hybridization }\end{array}$ & $\begin{array}{c}\text { rpoB PCR- } \\
\text { sequencing }\end{array}$ & $\begin{array}{c}\text { Biochemical } \\
\text { testing }\end{array}$ \\
\hline M. kansasii & 27 & 27 & 27 \\
Non-M. kansasii & 174 & 174 & 174 \\
\hline
\end{tabular}

The sensitivity and specificity of this DNA hybridization method performed with culture samples was $100 \%$. The negative strains by this DNA hybridization method were identified as $M$. tuberculosis (159 strains), M. avium (5 strains), M. intracellulare (8 strains), and M. flavescens (2 strain) by $r p o B$ DNA sequence analysis.

\section{DISCUSSION AND CONCLUSION}

There have been developed many diagnostic methods for mycobacterial infections containing conventional culture methods, PCR-based methods, and liquid culturebased mycobacterial detection systems, such the Bactec [7], MGIT [8], ESP [9], and BacT/Alert 3D [10]. There are many PCR-linked methods using 16S rRNA gene [11-14] and 16S-23S rRNA spacer region [3, 14] in mycobacteria. However, despite these efforts, a good standard protocol for detection and identification of $M$. kansasii has not yet been established because of various subtypes of M. kansasii.

In this study, we suggest that this DNA-DNA hybridization method assay using $M$. kansasii-specific rpoB DNA prob, kanp probe, could be useful for a rapid and precise detection for M. kansasii.

\section{ACKNOWLEDGMENTS}

This research was supported by Basic Science Research Program through the National Research Foundation of Korea (NRF) funded by the Ministry of Education, Science and Technology (2011-0014780) and (2011-0024912). 


\section{REFERENCES}

[1] K. C. Bloch, L. Zwerlin, M. J. Pletcher, J. A. Hahn, J. L. Gerberding, S. M. Ostroff, D. J. Vugia, and A. L. Reingold, "Incidence and clinical implications of isolation of Mycobacterium kansasii: results of a 5-year, population-based study," Annals of Internal Medicine, vol. 129, no 9, pp. 698-704, 1998.

[2] A. J. Evans, A. J. Crisp, R. B. Hubbard, A. Colville, S. A. Evans, and I. D. Johnston, "Pulmonary Mycobacterium kansasii infection: comparison of radiological appearances with pulmonary tuberculosis," Thorax, vol. 51, no. 12, pp. 1243-1247, 1996.

[3] E. Tortoli, A. Mariottini, and G. Mazzarelli, "Evaluation of INNOLiPA MYCOBACTERIA v2: improved reverse hybridization multiple DNA probe assay for mycobacterial identification," Journal of Clinical Microbiology, vol. 41, no. 9, pp. 4418-4420, 2003.

[4] A. Sajduda, A. Martin, F. Portaels, and J. C. Palomino, "hsp65 PCR-restriction analysis (PRA) with capillary electrophoresis for species identification and differentiation of Mycobacterium kansasii and Mycobacterium chelonae-Mycobacterium abscessus group," International Journal of Infectious Diseases, vol. 16, no. 3, pp. 193197, 2012.

[5] B. J. Kim, S. H. Lee, M. A. Lyu, S. J. Kim, G. H. Bai, G. T. Chae, E. C. Kim, C. Y. Cha, and Y. H. Kook, "Identification of mycobacterial species by comparative sequence analysis of the RNA polymerase gene (rpoB)," Journal of Clinical Microbiology, vol. 37, no. 6, pp. 1714-1720, 1999.

[6] S. K. Hong, B. J. Kim, Y. J. Yun, K. H. Lee, E. C. Kim, E. M. Park, Y. G. Park, G. H. Bai, and K. H. Kook, "Identification of Mycobacterium tuberculosis by PCR-linked reverse hybridization using specific rpoB oligonucleotide probes," Journal of Microbiological Methods, vol. 59, no. 1, pp. 71-79, 2004.

[7] D. Hillemann, E. Richter, and S. Rusch-Gerdes, "Use of the BACTEC Mycobacteria Growth Indicator Tube 960 automated system for recovery of Mycobacteria from 9,558 extrapulmonary specimens, including urine samples," Journal of Clinical Microbiology, vol. 44, no. 11, pp. 4014-1017, 2006.
[8] F. Z. Badak, D. L. Kiska, M. O'Connell, C. M. Nycz, C. Hartley, S. Setterquist, and R. L. Hopfer, Confirmation of the presence of Mycobacterium tuberculosis and other mycobacteria in mycobacterial growth indicator tubes (MGIT) by multiplex strand displacement amplification," Journal of Clinical Microbiology, vol. 35, no. 5, pp. 1239-1243, 1997.

[9] N. Williams-Bouyer, R. Yorke, H. I. Lee, and G. L. Woods, "Comparison of the BACTEC MGIT 960 and ESP culture system II for growth and detection of mycobacteria," Journal of Clinical Microbiology, vol. 38, no. 11, pp. 4167-4170, 2000.

[10] A. Carricajo, N. Fonsale, A. C. Vautrin, and G. Aubert, "Evaluation of BacT/Alert 3D liquid culture system for recovery of mycobacteria from clinical specimens using sodium dodecyl (lauryl) sulfate- $\mathrm{NaOH}$ decontamination," Journal of Clinical Microbiology, vol. 39, no. 10, pp. 3799-3800, 2001.

[11] V. J. Tevere, P. L. Hewitt, A. Dare, P. Hocknell, A. Keen, J. P. Spadoro, and K. K. Young, "Detection of Mycobacterium tuberculosis by PCR amplification with pan-Mycobacterium primers and hybridization to an M. tuberculosis-specific probe," Journal of Clinical Microbiology, vol. 34, no. 4, pp. 918-923, 1996.

[12] F. Portaels, J. Agular, K. Fissette, P. A. Fonteyne, H. de Beenhouwer, P. de Rijk, A. Guedenon, R. Lemans, C. Steunou, C. Zinsou, J. M. Dumonceau, and W. M. Meyers," Journal of Clinical Microbiology, vol. 35, no. 5, pp. 1097-1100, 1997.

[13] H. Stender, K. Lund, K. H. Petersen, O. F. Rasmussen, P. Hongmanee, H. Miorner, and S. E. Godtfredsen, "Fluorescence In situ hybridization assay using peptide nucleic acid probes for differentiation between tuberculous and nontuberculous mycobacterium species in smears of mycobacterium cultures," Journal of Clinical Microbiology, vol. 37, no. 9, pp. 2760-2765, 1999.

[14] P. N. Suffys, A. da Silva-Rocha, M. de Oliveira, C. E. Campos, A. M. Barreto, F. Portaels, L. Rigouts, G. Wouters, G. Jannes, G. van Reybroeck, W. Mijs, and B. Vanderborght, "Rapid identification of Mycobacteria to the species level using INNO-LiPA Mycobacteria, a reverse hybridization assay," Journal of Clinical Microbiology, vol. 39, no. 12, pp. 4477-4482, 2001.

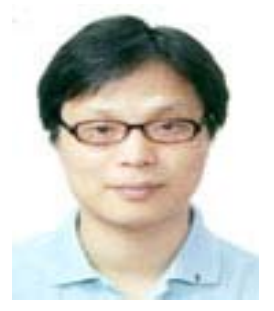

Tae-Dong Kweon

He graduated from Dept. of Anesthesiology and Pain Medicine, College of Medicine, Yonsei University taking the B.S in 1996. He obtained a M.S from Dept. of Anesthesiology and Pain Medicine, College of Medicine, Yonsei University in 2005. He obtained a Ph.D. from Dept. of Anesthesiology and Pain Medicine, College of Medicine, Yonsei University in 2010. He is assistant professor in Dept. of Anesthesiology and Pain Medicine, College of Medicine, Yonsei University, Korea. 


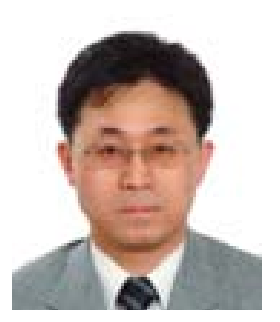

\section{Sun-Joon Bai}

He graduated from Dept. of Anesthesiology and Pain Medicine, College of Medicine, Yonsei University taking the B.S in 1986. He obtained a M.S from Dept. of Anesthesiology and Pain Medicine, College of Medicine, Yonsei University in 2005. He obtained a Ph.D. from Dept. of Anesthesiology and Pain Medicine, College of Medicine, Yonsei University in 2010. He is professor in Dept. of Anesthesiology and Pain Medicine, College of Medicine, Yonsei University, Korea.

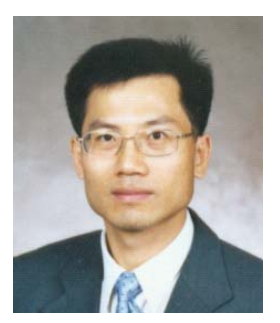

\section{Chang-Shik Choi}

He graduated from Dept. of Chemistry Chungnam National University taking the B.S in 1985 . He obtained a M.S from Dept. of Chemistry, Chungnam National University in 1987. He obtained a Ph.D. from Dept. of Chemical Bioengineering, University of Tokyo in 2000. He is a professor and Head in Department of Oriental Medicine Resources, Natural Sciences Division, Far East University, Korea.

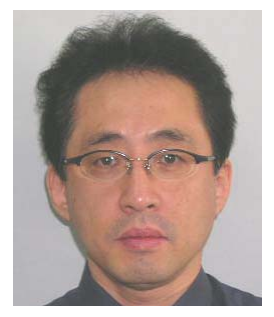

\section{Seong-Karp Hong}

He graduated from Dept. of Biology Korea University taking the B.S in 1983. He obtained a M.S from Dept. of Biology, Korea University in 1985. He obtained a Ph.D. from Dept. of Biology, Korea University in 1997. He is professor in Division of Bio and Health Sciences, Mokwon University 